\title{
Erythrocyte $\mathrm{Hb}-\mathrm{S}$ Concentration
}

\author{
AN IMPORTANT FACTOR IN THE LOW OXYGEN \\ AFFINITY OF BLOOD IN SICKLE CELL ANEMIA
}

\author{
M. Seakins, W. N. Gibbs, P. F. Milner, and J. F. Bertles \\ From the Departments of Chemistry and Hematology, University of the West \\ Indies, Kingston, Jamaica, and the Hematology Division, Medical Service, \\ St. Luke's Hospital Center, New York 10025
}

\begin{abstract}
A B S TRACT The blood in sickle cell anemia has a very low oxygen affinity and, although 2,3-diphosphoglycerate $(2,3-\mathrm{DPG})$ is increased, there is doubt as to whether this is the only factor responsible. In this study of 15 patients with sickle cell anemia ( $\mathrm{Hb} \mathrm{SS}$ ) no correlation was found between oxygen affinity $\left(P_{50}\right.$ at $\mathrm{pH} 7.13$ ) and 2,3-DPG in fresh venous blood. Whole populations of $\mathrm{Hb} \mathrm{SS}$ erythrocytes were therefore separated, by an ultracentrifuge technique, into fractions of varying density. The packed red cell column was divided into three fractions; a bottom fraction rich in deformed cells or irreversibly sickled cells (ISC), with a very high mean corpuscular hemoglobin concentration (MCHC) ; a middle fraction containing cells with the highest content of fetal hemoglobin; and a top fraction containing reticulocytes and discoid cells but free of deformed cells. Oxygen affinity was shifted to the right in all layers (mean $\mathrm{P}_{50}(\mathrm{pH} 7.13) \pm 1 \mathrm{SD}$ : top $46.3 \pm 2.9$ $\mathrm{mm} \mathrm{Hg}$ : middle $49.8 \pm 4.9 \mathrm{~mm} \mathrm{Hg}$; bottom $61.0 \pm 5.8$ $\mathrm{mm} \mathrm{Hg}$ ) compared with normal blood (top $32.1 \pm 0.7$ $\mathrm{mm} \mathrm{Hg}$; bottom $30.1 \pm 0.5 \mathrm{~mm} \mathrm{Hg}$ ). 2,3-DPG was increased in the top fraction, but was low or normal in the bottom fraction (top $21.8 \pm 3.4 \mu \mathrm{mol} / \mathrm{g} \mathrm{Hb}$; middle $17.7 \pm 2.2 \mu \mathrm{mol} / \mathrm{g} \mathrm{Hb}$; bottom $13.8 \pm 3.1 \mu \mathrm{mol} / \mathrm{g} \mathrm{Hb}$; normal whole blood $14.3 \pm 1.2 \mu \mathrm{mol} / \mathrm{g} \mathrm{Hb}$ ). The level
\end{abstract}

Dr. Seakins is a Lecturer, Department of Chemistry, University of the West Indies; Dr. Gibbs is Senior Lecturer, Sub-Department of Hematology, University of the West Indies; Dr. Milner is Senior Lecturer and Head, Sub-Department of Hematology, University of the West Indies; and Dr. Bertles is Director, Hematology Division, Medical Service, St. Luke's Hospital Center, New York 10025 and Career Scientist, Health Research Council of the city of New York.

Received for publication 8 February 1972 and in revised form 17 October 1972. of 2,3-DPG in top fractions could not account for the degree of right shift of $P_{50}$, and in the middle and bottom fractions the even greater right shifts were associated with lower levels of 2,3-DPG. Top fraction cells depleted of 2,3-DPG had a higher, but still abnormally low, oxygen affinity. A strong relationship was found between oxygen affinity and MCHC. The fractions with the greatest right shift in $\mathrm{P}_{\text {so }}$ had the highest $\mathrm{MCHC}$ (top $32.4 \pm 2.0$; middle $36.2 \pm 3.1$; bottom $44.6 \pm 3.2 \mathrm{~g} /$ $100 \mathrm{ml}$, respectively) and the plot of $\mathrm{P}_{\mathrm{s}_{0}}$ vs. MCHC showed a positive correlation $(r=0.90, P<0.001)$.

The red cell population in sickle cell anemia is not homogeneous but contains cells of widely varying $\mathrm{Hb} \mathrm{F}$ content, 2,3-DPG, and hemoglobin concentration. Paradoxically, the cells with the lowest $\mathrm{O}_{2}$ affinity have the lowest 2,3-DPG, but they also have the highest concentration of $\mathrm{Hb} \mathrm{S}$. The dense, deformed cell called the ISC is but the end stage in a process of membrane loss and consequent increase in hemoglobin concentration. The $\mathrm{P}_{50}$ of $\mathrm{Hb}$ SS blood is, to a large extent, determined by the presence of these cells $(r=0.85, P<0.001)$. Increased concentration of $\mathrm{Hb} \mathrm{S}$ in the cell favors deoxygenation and crystallization even at relatively high $\mathrm{Po}_{0_{2}}$. Lowered affinity for oxygen appears to be closely associated with $\mathrm{Hb} \mathrm{S}$ concentration and not with 2,3DPG content.

\section{INTRODUCTION}

The affinity of adult red blood cells for oxygen is lower than the affinity of solutions of the hemoglobin they contain (1-4). It is now well established that this effect is due primarily to intracellular organic phosphates (5-9) of which the most important is 2,3-diphos- 
phoglycerate $(2,3-D P G),{ }^{1}$ which acts as a fine regulator of hemoglobin function within the red cell $(10)$.

In a number of dissimilar conditions associated with hypoxemia, an abnormal shift to the right of the red cell oxygen-hemoglobin $\left(\mathrm{O}_{2}-\mathrm{Hb}\right)$ equilibrium curve has been observed (11-14). Many patients with anemia, due to a variety of causes, have a blood oxygen affinity that is lower than normal (15-17). Recent studies (18, 19) have shown that in both hypoxic hypoxia and anemic hypoxia there is an increase in 2,3-DPG. In hypoplastic anemias it seems clear that the 2.3-DPGinduced shift in the $\mathrm{O}_{2}-\mathrm{Hb}$ equilibrium curve may compensate for up to half the oxygen deficit implicit in the anemia (19). Some hemoglobinopathies may be associated with altered oxygen affinity because of the nature of the substitution in the hemoglobin molecule (20-22) or because the substitution involves one of the binding sites for 2,3-DPG (23). The higher oxygen affinity of cord blood has recently been explained by the reduced interaction between fetal hemoglobin ( $\mathrm{Hb} F$ ) and 2,3DPG $(24,25)$.

The very low oxygen affinity of blood in sickle cell anemia ( $\mathrm{Hb} \mathrm{SS}$ ) is well documented $(26-28)$, but the $\mathrm{O}_{2}-\mathrm{Hb}$ equilibrium curve of sickle cell hemoglobin $(\mathrm{Hb}$ $\mathrm{S})$ in solution is not different from that for $\mathrm{Hb} \mathrm{A}$ $(29,8)$ and the interactions of both hemoglobins with 2,3-DPG appears to be of the same order (8). Increased amounts of 2,3-DPG have been demonstrated in $\mathrm{Hb}$ SS blood $(30,31)$. There is also a good correlation between the degree of anemia (hemoglobin level or hematocrit) and $P_{50}(28,32)$. For these reasons Bunn and Jandl (10) and Bunn and Briehl (8) ascribed the very low oxygen affinity of $\mathrm{Hb} \mathrm{SS}$ cells to hypoxia-induced increases in red cell 2,3-DPG, and the work of Bromberg and Andrade (31) tended to confirm this assumption. Charache, Grisolia, Fiedler, and Hellegers.(30), however, could not find any correlation between the degree of anemia in $\mathrm{Hb} \mathrm{SS}$ subjects and the level of their red cell 2,3-DPG, and they could not reproduce the very low affinity of whole blood by adding 2,3-DPG to lysates of $\mathrm{Hb} \mathrm{SS}$ cells.

The present study of the oxygen affinity and 2,3-DPG content of red cells from $\mathrm{Hb} \mathrm{SS}$ patients was designed to find out whether the extreme right shift in the $\mathrm{O}_{2}-\mathrm{Hb}$ equilibration curve is solely due to anemia-associated 2,3-DPG increase, or whether the intrinsic molecular defect associated with the sickling phenomenon may be playing an important part. To this end, whole populations of $\mathrm{Hb} \mathrm{SS}$ erythrocytes were separated by ultra-

\footnotetext{
${ }^{1}$ Abbreviations used in this paper: 2,3-DPG, 2,3-diphosphoglycerate; $\mathrm{Hb} \mathrm{F}$, fetal hemoglobin; $\mathrm{Hb} \mathrm{SS}$, sickle cell anemia; $\mathrm{Hb} \mathrm{S}$, sickle cell hemoglobin; ISC, irreversible sickle cells; $\mathrm{MCH}$, mean cell hemoglobin; $\mathrm{MCHC}$, mean corpuscular hemoglobin concentration; $\mathrm{MCV}$, mean cell volume; $\mathrm{O}_{2}-\mathrm{Hb}$, oxygen-hemoglobin.
}

centrifugation into fractions of varying density. These were then analyzed for oxygen affinity, 2,3-DPG content, and concentration of $\mathrm{Hb} \mathrm{S}$ and $\mathrm{Hb} \mathrm{F}$.

\section{METHODS}

Patients were selected from the sickle cell anemia clinic at the University Hospital, Kingston, Jamaica; six males and nine females with ages ranging from 15 to $47 \mathrm{yr}$. The diagnosis of $\mathrm{Hb}$ SS disease was well established in each, and none had been transfused during the previous 6 mo.

Fresh venous blood, anticoagulated with heparin and with most of the white cells and platelets removed, was adjusted to a hematocrit of 60 , oxygenated, and centrifuged in the SW 50L swinging-bucket rotor of a Spinco model L ultracentrifuge ${ }^{2}$ at $170,000 \mathrm{~g}$ for $30 \mathrm{~min}$ as previously described (33). After centrifugation, the supernatant plasma and any buffy coat were removed and the upper third of the red cell column was aspirated by puncturing the side of the tube with a wide-bore needle attached to a syringe (top layer). A tube slicer was used to divided the remaining cell column into two (middle and bottom) layers. Each cell layer was gently and completely resuspended in autologous plasma. Smears prepared on cover slips from the whole blood sample and from each layer were examined for counts of irreversibly sickled cells (ISC). Reticulocytes were enumerated by routine techniques. Hemoglobin was measured as cyanmethemoglobin. Hematocrits were measured to a precision of $0.5 \%$ in microcapillary tubes examined on an expanded scale reader. ${ }^{3}$ Red cells were counted by an electronic particle counter. ${ }^{4} \mathrm{MCHC}$, mean cell volume $(\mathrm{MCV})$, and mean cell hemoglobin $(\mathrm{MCH})$ were calculated. $\mathrm{MC}(\mathrm{Hb} \mathrm{S}) \mathrm{C}$ was calculated as $[\mathrm{Hb}]-\left[\begin{array}{ll}\mathrm{Hb} & \mathrm{F}\end{array} \times\right.$ 100 /hematocrit (where the concentrations are in $\mathrm{g} / 100$ $\mathrm{ml}$ ), ignoring $\mathrm{Hb} \mathrm{A}_{2}$. All tests were performed in duplicate.

Oxygen dissociation determinations were performed immediately on samples from each layer and from whole blood by the method of Bellingham and Huehns (34). Saline-washed red cells were suspended in $4 \mathrm{ml}$ of isotonic (310 mM) phosphate buffer, $\mathrm{pH} 7.13^{5}$ (5.56 $\mathrm{g} \mathrm{NaH}_{2} \mathrm{PO}_{4}$ $\cdot 2 \mathrm{H}_{2} \mathrm{O}+14.065 \mathrm{~g} \mathrm{Na}_{2} \mathrm{HPO}_{4} \cdot 2 \mathrm{H}_{2} \mathrm{O}$ in 1 liter) or $\mathrm{pH} 7.47^{5}$ (2.84 g NaH $\mathrm{PO}_{4} \cdot 2 \mathrm{H}_{2} \mathrm{O}+16.308 \mathrm{~g} \mathrm{Na}_{2} \mathrm{HPO}_{4} \cdot 2 \mathrm{H}_{2} \mathrm{O}$ in 1 liter) in $70-\mathrm{ml}$ Pyrex tonometers attachẹd to $1-\mathrm{cm}$ silica spectrophotometer cells. The red-cell suspension was first deoxygenated by a series of three evacuations of the tonometer on a rotary pump and three 3 -min rotations in a water-bath at $37^{\circ} \mathrm{C}$. The spectrum from 600 to $520 \mathrm{~nm}$ was recorded in a Unicam SP 800 A recording spectrophotometer using the forward cell position. A measured volume of air was added and the tonometer contents equilibrated again at $37^{\circ} \mathrm{C}$ for $3 \mathrm{~min}$. The procedure was repeated $6-12$ times and finally the tonometer was filled with $\mathrm{O}_{2}$ at atmospheric pressure to achieve $100 \%$ saturation. The partial pressures of oxygen were determined by ideal gas-law calculations, making allowance for the ambient humidity. The values for percentage saturation by $\mathrm{O}_{2}$ were determined by means of the optical-density values at characteristic wavelengths of 560 and $578 \mathrm{~nm}$. Isosbestic points were sharp in acceptable experiments on all fractions. Each run was performed in duplicate and at least 12 points obtained for each dissociation curve. The behavior of red cells in this system was tested by repeat runs on suspensions taken

\footnotetext{
${ }^{2}$ Beckman Instruments, Inc., Spinco Div., Palo Alto, Calif.

'International Equipment Co., Needham Heights, Mass.

Coulter Electronics, Inc., Hialeah, Fla.
}

${ }^{5} 25^{\circ} \mathrm{C}$. 
TABLE I

Pertinent Hematologic Findings in 15 Hb SS Patients

\begin{tabular}{|c|c|c|c|c|c|c|c|c|c|}
\hline Subject & Age & Sex & $\mathrm{Hb}$ & Het & Reticulocytes & $\mathbf{P}_{50}{ }^{*}$ & DPG & ISC & $\mathrm{Hb} \mathrm{F}$ \\
\hline & & & $\mathrm{g} / 100 \mathrm{ml}$ & $\%$ & $\%$ & $m m \mathrm{Hg}$ & $\mu \mathrm{mol} / \mathrm{g} \mathrm{Hb}$ & $\%$ & $\%$ \\
\hline P. D. & 20 & $\mathbf{M}$ & 11.6 & 33.5 & 3.6 & 42.1 & 15.9 & 3.0 & 11.6 \\
\hline P. B. & 14 & $F$ & 7.9 & 25.0 & 5.6 & 44.8 & 15.2 & 3.2 & 5.0 \\
\hline V. G. & 32 & $F$ & 7.5 & 22.0 & 6.0 & 45.3 & 27.5 & 5.0 & 9.0 \\
\hline D. C. & 44 & $\mathrm{~F}$ & 5.4 & 17.5 & 9.2 & 46.0 & 14.2 & 6.5 & 9.8 \\
\hline V. P. & 29 & $\mathbf{M}$ & 10.7 & 31.0 & 8.0 & 48.4 & 24.1 & 14.8 & 2.1 \\
\hline J. D. & 17 & $\mathrm{~F}$ & 7.2 & 20.5 & 8.0 & 49.2 & 18.6 & 14.0 & 2.1 \\
\hline J. F. & 20 & $\mathbf{M}$ & 6.8 & 20.5 & 3.8 & 49.6 & 19.4 & 10.0 & 3.1 \\
\hline A. B. & 24 & $\mathrm{~F}$ & 8.9 & 28.0 & 5.1 & 50.3 & 22.7 & 16.0 & 5.8 \\
\hline E. B. & 18 & $\mathrm{~F}$ & 9.0 & 26.0 & 18.0 & 50.3 & 16.4 & 10.0 & 3.3 \\
\hline C. B. & 20 & $\mathbf{M}$ & 8.0 & 22.0 & 8.8 & 51.5 & 17.0 & 21.0 & 2.9 \\
\hline W. H. & 21 & M & 8.6 & 25.0 & 5.0 & 51.9 & 17.2 & 14.0 & 1.5 \\
\hline M. V. & 20 & $\mathrm{~F}$ & 6.1 & 17.5 & 6.0 & 52.2 & 20.7 & 15.0 & 3.6 \\
\hline C. F. & 15 & $\mathrm{~F}$ & 6.7 & 18.5 & 10.0 & 53.4 & 20.3 & 26.0 & 1.4 \\
\hline L. L. & 47 & $\mathrm{~F}$ & 5.7 & 15.5 & 20.0 & 54.2 & 12.9 & 25.0 & 1.5 \\
\hline J. B. & 24 & $\mathbf{M}$ & 7.3 & 22.0 & 6.4 & 56.1 & 17.8 & 18.0 & 0.4 \\
\hline
\end{tabular}

${ }^{*} \mathrm{pH} 7.13,37^{\circ} \mathrm{C}$.

through the deoxygenation-reoxygenation procedure three times.

2,3-DPG was measured on samples from each layer prepared by the method of Beutler, Meul, and Wood (35) using the method of Krimsky (36). Results were expressed as micromoles of 2,3-DPG per gram $\mathrm{Hb}$ in the sample examined. $\mathrm{Hb} F$ was measured on all samples by the alkali resistance method of Betke, Marti, and Schlicht (37). ISC counts were performed as previously described (33).

\section{RESULTS}

Oxygen affinity and 2,3-DPG in whole blood. The hemoglobin level, reticulocyte count, ISC count, $\mathrm{O}_{2}$ affinity, 2,3-DPG concentration, and $\mathrm{Hb} F$ proportion for the $15 \mathrm{Hb}$ SS patients are given in Table I, where the patients are arranged in order of decreasing oxygen

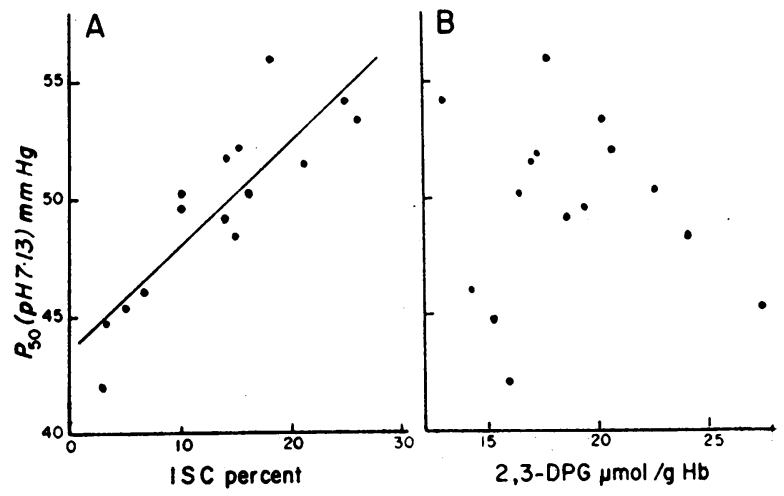

Frgure 1 Relationship between oxygen affinity $\left(\mathrm{P}_{50}\right)$ and (A) ISC percentage, (B) 2,3-DPG, in unfractionated red cells of patients with sickle cell anemia. In (A) the regression line $P_{\text {so(r. 28) }}=0.456$ ISC +43.6 is shown $(r=0.86$, $P<0.001$ ). affinity of their red cells. In our laboratory, normal adult whole blood has a 2,3-DPG content of $14.3 \pm 1.2$ (SD) $\mu \mathrm{mol} / \mathrm{g} \mathrm{Hb}$ and, at $37^{\circ} \mathrm{C}$ in phosphate buffer $\mathrm{pH}$ 7.13 , is half saturated with oxygen at a pressure ( $\left.P_{\infty}\right)$ of $31.4 \pm 0.9 \mathrm{~mm} \mathrm{Hg}$. In a previous study of $84 \mathrm{Hb} \mathrm{SS}$ patients $^{\circ} \mathrm{P}_{\mathrm{so}}(\mathrm{pH}$ 7.13) values ranged from 42.5 to $53 \mathrm{~mm} \mathrm{Hg}$. In the present series they ranged from 42.1 to $56.1 \mathrm{~mm} \mathrm{Hg}$. No significant correlation was found between $\mathrm{P}_{\mathrm{so}}$ and 2,3-DPG $(r=0.08, P>0.5)$ but there was a significant positive correlation between $\mathrm{P}_{\text {so }}$ and ISC count $(r=0.85, P<0.001)$ Fig. 1 .

Ultracentrifugation. The purpose of centrifugation was to separate the whole red cell population into subpopulations of varying density. ISC were concentrated in the bottom fractions and only few were found in the middle and top layers, depending on the original numbers of these deformed cells in the whole cell sample. The mean ISC counts were: bottom $59 \%$, middle $7 \%$, and top $1.5 \%$. The top fractions contained most of the reticulocytes but some were also found in middle fractions. In only two patients (P. D. and D. C.) was the level of $\mathrm{Hb} \mathrm{F}$ in the bottom fractions greater than $5 \%$ of the hemoglobin in that fraction (6.2 and $6.5 \%$ respectively). These two patients had the highest whole blood $\mathrm{Hb} F$ (Table I). Mean $\mathrm{Hb}$ F was lowest in the bottom fraction and highest in the middle fraction (Table II) but the difference between top and middle fractions was not significant. The highest level of $\mathrm{Hb} \mathrm{F}$ in any fraction was found in the middle fraction for patient P. D. $(14.5 \%)$. Four patients had slightly higher $\mathrm{Hb} \mathrm{F}$ in top than in middle fractions. Because

- Bellingham et al. Unpublished results. 
TABLE II

Red Cell Indices, $P_{50}, 2,3-D P G$, and $H b F$ in Whole Blood and Ultracentrifuge Fractions, from $15 \mathrm{Hb}$ SS Patients

\begin{tabular}{lcccccc}
\hline Fraction & $\mathrm{MCHC} \pm 1 \mathrm{SD}$ & $\mathrm{MCH} \pm 1 \mathrm{SD}$ & $\mathrm{MCV} \pm 1 \mathrm{SD}$ & $\mathrm{P}_{\mathbf{6 0}} \pm 1 \mathrm{SD}$ & $\mathrm{DPG} \pm 1 \mathrm{SD}$ & $\mathrm{Hb}$ F $\pm 1 \mathrm{SD}$ \\
\hline & $g / 100 \mathrm{ml}$ & $\boldsymbol{p g}$ & $\mu m^{3}$ & $m m \mathrm{Hg}$ & $\mu m o l / g$ Hb & $\%$ \\
Whole blood & $33.9 \pm 1.8$ & $31.6 \pm 2.0$ & $93 \pm 6$ & $49.7 \pm 3.8$ & $18.7 \pm 3.9$ & $4.2 \pm 3.4$ \\
Top & $32.4 \pm 2.0$ & $33.0 \pm 1.9$ & $101 \pm 7$ & $46.3 \pm 2.9$ & $21.8 \pm 3.4$ & $4.7 \pm 3.4$ \\
Middle & $36.2 \pm 3.1$ & $33.0 \pm 2.1$ & $87 \pm 10$ & $49.8 \pm 4.9$ & $17.7 \pm 2.2$ & $4.9 \pm 3.5$ \\
Bottom & $44.6 \pm 3.2$ & $33.4 \pm 2.6$ & $73 \pm 7$ & $61.0 \pm 5.8$ & $13.8 \pm 3.1$ & $2.6 \pm 2.0$ \\
\hline
\end{tabular}

${ }^{*} \mathrm{pH} 7.13,37^{\circ} \mathrm{C}$.

of the lower levels of $\mathrm{Hb} \mathrm{F}$ in the bottom fractions, where $\mathrm{MCHC}$ was high, all the results were examined for a correlation between $\mathrm{Hb} \mathrm{F}$ and $\mathrm{MCHC}$, but none was found. Only three MCHC exceeded $45 \mathrm{~g} / 100 \mathrm{ml}$ and in two of these $\mathrm{Hb} \mathrm{F}$ was less than $1.0 \%$ and in the third $2.6 \%$.

The relationship of $\mathrm{MCHC}$ to $\mathrm{MCV}$ and $\mathrm{MCH}$ is shown in Fig. 2. $\mathrm{MCHC}$ increased with increasing density so that the bottom fraction contained cells with the highest MCHC. MCV decreased with increasing density, but $\mathrm{MCH}$ remained constant. These indices
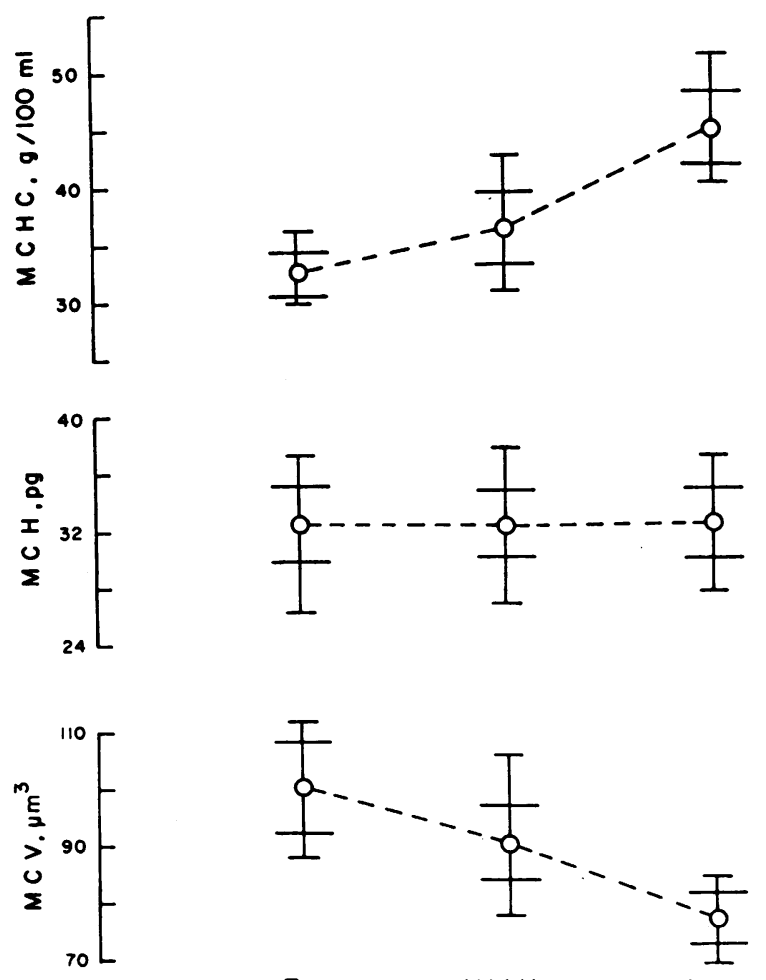

TOP

Middle

Boltom

FIGURE 2 Mean corpuscular hemoglobin concentration ( $\mathrm{MCHC})$, mean corpuscular hemoglobin $(\mathrm{MCH})$, and mean corpuscular volume (MCV) of top, middle, and bottom fractions of $\mathrm{Hb} \mathrm{SS}$ erythrocytes separated by ultracentrifugation. confirmed the appearance of the red cells in stained smears from the different fractions. In particular, the concentration of small, darkly stained, and mainly deformed cells (ISC) in the bottom fraction is confirmed by these indices (Table II). Corrections for trapped plasma were not made in the present study. Previous studies on $\mathrm{Hb}$ SS blood centrifugation (38) indicate, however, that all our MCV values would be decreased by $5 \%$ and all our $\mathrm{MCHC}$ values increased by $5 \%$ if this correction was applied.

As $\mathrm{MCH}$ was constant, 2,3-DPG was expressed as micromoles per gram $\mathrm{Hb}$ rather than as micromoles per

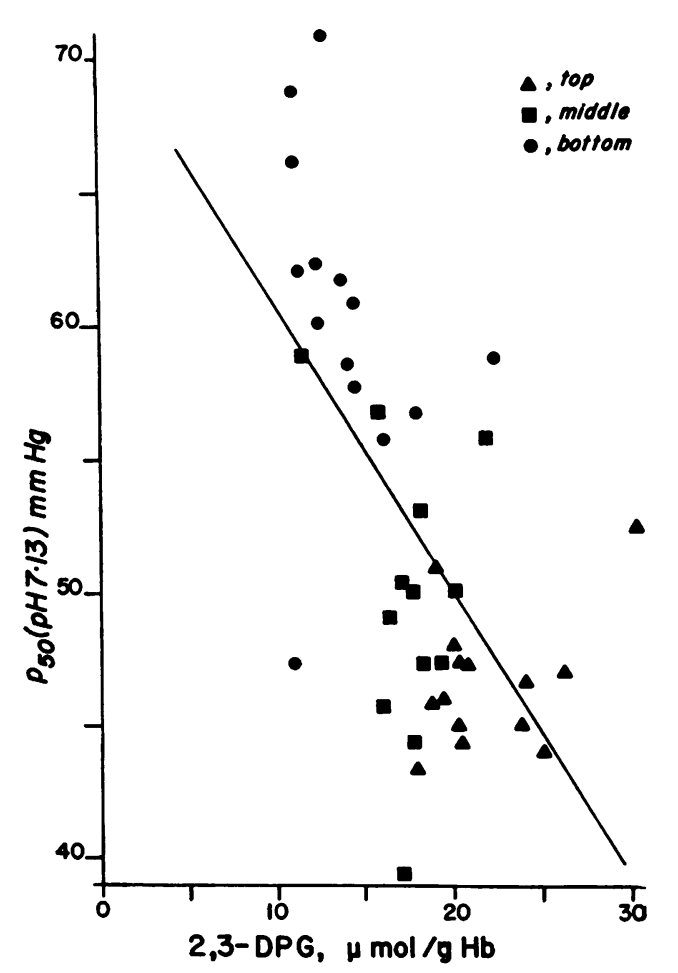

FIGURE 3 The relationship between oxygen affinity $\left(P_{B_{0}}\right)$ and 2,3-DPG (micromoles per gram $\mathrm{Hb}$ ) in fractions from $\mathrm{Hb}$ SS erythrocytes separated by ultracentrifugation. The regression line is drawn from the equation $\mathrm{P}_{\mathrm{s}_{0}(7.13)}=71.7-$ 1.08 DPG. $(r=-0.61, P<0.001)$. Compare with Fig. 1 . 


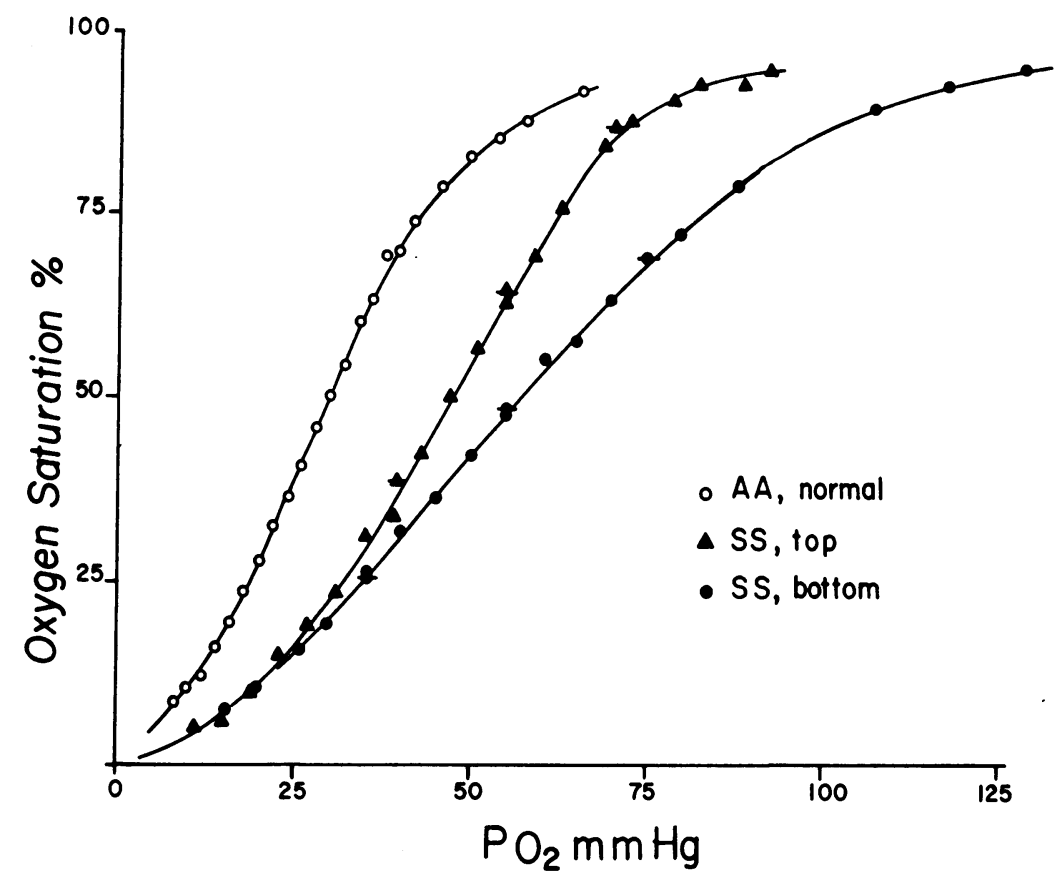

Figure $4 \mathrm{O}_{2}-\mathrm{Hb}$ equilibrium curves of red cells from top and bottom fractions of $\mathrm{Hb} \mathrm{SS}$ erythrocytes (patient V. P.) separated by ultracentrifugation and suspended in phosphate buffer $\mathrm{pH} 7.13$ at $37^{\circ} \mathrm{C}$. A curve for normal cells, under the same conditions, is also shown. Points for cells taken through the deoxygenation procedure three times are indicated by horizontal lines. The curves for the middle fraction and unfractionated $\mathrm{Hb} \mathrm{SS}$ cells ( $\mathrm{P}_{5_{0}}$ $48.4 \mathrm{~mm} \mathrm{Hg}$ ) have been omitted for clarity (see text).

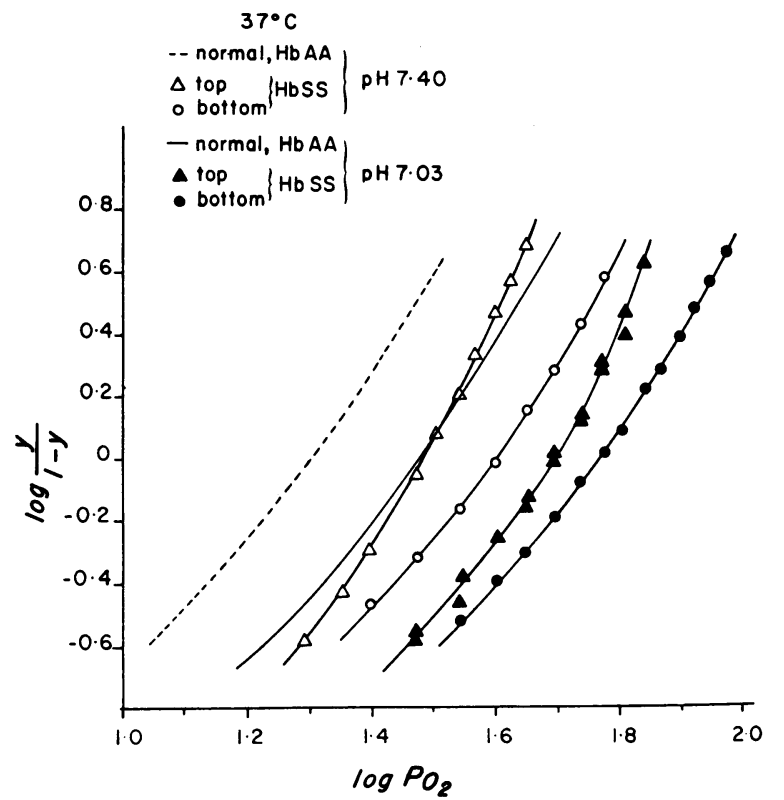

FIGURE $5 \mathrm{O}_{2}-\mathrm{Hb}$ equilibrium curves for top and bottom fractions of $\mathrm{Hb}$ SS erythrocytes (patient J. B.) compared with normal cells (subject M. S.). The data are plotted according to Hill's equation, $\log (y / 1-y)=\log \left(\mathrm{P}_{2} /\right.$ $\left.\mathrm{P}_{50}\right)^{n}$. The $\mathrm{pH}$ values are those of phosphate buffers measured at $37^{\circ} C$. Normal, $(\mathrm{pH} 7.40) n=2.6,(\mathrm{pH} 7.03) n=$ 2.7 ; Hb SS top, $(\mathrm{pH} 7.40) n=3.3,(\mathrm{pH} \mathrm{7.03)} n=3.1 ; \mathrm{Hb}$ SS bottom, $(\mathrm{pH} 7.40) n=2.7,(\mathrm{pH} 7.03) n=2.6$. liter of packed cells. Table II shows that 2,3-DPG was low $(13.8 \pm 3.1 \mu \mathrm{mol} / \mathrm{g} \mathrm{Hb})$ in the ISC-rich bottom fraction (i.e., the fraction with the lowest oxygen affinity). 2,3-DPG was higher in the top fraction (21.8 $\pm 3.4 \mu \mathrm{mol} / \mathrm{g} \mathrm{Hb})$ and in the middle fraction $(17.7 \pm 2.2$ $\mu \mathrm{mol} / \mathrm{g} \mathrm{Hb})$. The plot for all the fractions from the $\mathrm{Hb}$ SS patients of $\mathrm{P}_{50}(\mathrm{pH} 7.13$ ) against 2,3-DPG level showed a negative (inverse) relationship (Fig. 3 ).

One example of $\mathrm{O}_{2}-\mathrm{Hb}$ equilibrium curves obtained from top and bottom fractions of ultracentrifuged $\mathrm{Hb}$ SS blood (subject V. P., Table I) is shown in Fig. 4. In all experiments the curve for the ISC-rich bottom fraction was to the extreme right of those for the other fractions. The curve for the middle fraction always fell between those for the top and bottom and was always close to that for the unfractionated erythrocytes. The curve for the top fraction was to the left of these, but always well to the right of the curve for cells from normal ( $\mathrm{Hb} \mathrm{AA}$ ) blood. Fractions with the highest concentration of ISC (up to $90 \%$ in some bottom fractions) had the highest $\mathrm{P}_{50}$ values. No significant difference was found between the MCHC of cells measured before and after the manipulation of the oxygen dissociation experiments, and the curves on cells from top and bottom fractions did not alter after the suspensions had been deoxygenated and reoxygenated three times. $\mathrm{O}_{2}-\mathrm{Hb}$ equilibrium curves, performed 
TABLE III

Red Cell Indices, $P_{50}, D P G$, and $H b F$ in Fractions from Ultracentrifuged Blood of Normal and Sickle Cell Trait Subjects and a Heterozygote for both $\mathrm{Hb} S$ and the Gene for Hereditary Persistence of Fetal Hemoglobin (Hb-S/HPFH)

\begin{tabular}{|c|c|c|c|c|c|c|}
\hline Fraction & $\mathrm{MCHC} \pm 1 \mathrm{SD}$ & $\mathrm{MCH} \pm 1 \mathrm{SD}$ & $\mathrm{MCV} \pm 1 \mathrm{SD}$ & $\mathrm{P}_{50} * \pm 1 \mathrm{SD}$ & $\mathrm{DPG} \pm 1 \mathrm{SD}$ & $\mathrm{Hb} F \pm 1 \mathrm{SD}$ \\
\hline & $\mathrm{g}_{\prime}^{\prime} 100 \mathrm{ml}$ & $p g$ & $\mu m^{3}$ & $m m \mathrm{Hg}$ & $\mu m o l / g H b$ & $\%$ \\
\hline \multicolumn{7}{|c|}{ Normal subjects $(\mathrm{n}=6)$} \\
\hline Whole blood & $32.5 \pm 0.9$ & $28.6 \pm 2.7$ & $89 \pm 6$ & $31.2 \pm 0.7$ & $14.0 \pm 1.6$ & $0.4 \pm 0.2$ \\
\hline Top & $32.3 \pm 2.2$ & $29.3 \pm 3.2$ & $93 \pm 7$ & $32.1 \pm 0.7$ & $15.7 \pm 0.9$ & $0.5 \pm 0.4$ \\
\hline Middle & $32.8 \pm 1.6$ & $29.2 \pm 2.9$ & $91 \pm 5$ & $31.3 \pm 0.6$ & $14.5 \pm 0.7$ & $0.4 \pm 0.2$ \\
\hline Bottom & $35.2 \pm 2.4$ & $29.0 \pm 2.8$ & $85 \pm 6$ & $30.1 \pm 0.3$ & $12.0 \pm 1.1$ & $0.4 \pm 0.3$ \\
\hline \multicolumn{7}{|c|}{ Sickle cell trait $(n=6)$} \\
\hline Whole blood & $32.0 \pm 1.3$ & $28.9 \pm 1.9$ & $90 \pm 4$ & $35.5 \pm 1.5$ & $14.9 \pm 2.8$ & $0.5 \pm 0.2$ \\
\hline Top & $31.7 \pm 1.6$ & $29.0 \pm 1.7$ & $92 \pm 4$ & $35.3 \pm 1.6$ & $17.4 \pm 2.2$ & $0.4 \pm 0.2$ \\
\hline Middle & $32.5 \pm 1.4$ & $28.5 \pm 2.0$ & $88 \pm 6$ & $36.2 \pm 0.8$ & $15.7 \pm 1.6$ & $0.5 \pm 0.5$ \\
\hline Bottom & $35.4 \pm 1.8$ & $28.8 \pm 2.3$ & $80 \pm 6$ & $36.3 \pm 0.6$ & $12.4 \pm 1.5$ & $0.5 \pm 0.3$ \\
\hline \multicolumn{7}{|c|}{$\mathrm{Hb}-\mathrm{S} / \mathrm{HPFH}(\mathrm{n}=1)$} \\
\hline Whole blood & 33.7 & 27.3 & 82.1 & 36.5 & 11.4 & 20.5 \\
\hline Top & 34.0 & 28.5 & 83.8 & 35.7 & 12.2 & 16.3 \\
\hline Middle & 35.0 & 27.3 & 77.9 & 36.4 & 11.5 & 19.0 \\
\hline Bottom & 37.3 & 26.8 & 71.9 & 37.5 & 10.1 & 16.0 \\
\hline
\end{tabular}

${ }^{*} \mathrm{pH} 7.13,37^{\circ} \mathrm{C}$.

at $\mathrm{pH} 7.47$ as well as at $\mathrm{pH} 7.13$, showed a normal Bohr effect in both top and bottom fractions.

Hill plots for all fractions were curved upwards over the whole range of oxygen pressure, a finding noted also by Bromberg and Andrade (31). A typical Hill plot is shown in Fig. 5, where curves from top and bottom fractions for patients J. B. (Table I) are compared with curves from unfractionated normal cells (subject M. S.).

Results for normal erythrocytes (Hb AA) and erythrocytes from sickle cell trait subjects ( $\mathrm{Hb} A S$ ), separated into three equal fractions after ultracentrifugation, are given in Table III, for comparison with the $\mathrm{Hb}$ SS results. Normal blood had a higher level of 2,3-DPG in young (top fraction) than old (bottom fraction) red cells. This has been noted previously (10). The lower 2,3-DPG of the denser, older red cells in normal blood is associated with a higher oxygen affinity (the reverse of the situation found in red cells containing $\mathrm{Hb} \mathrm{S}$ ). $\mathrm{Hb}$ AS blood had a consistently lower oxygen affinity than normal blood, but there were only small differences in the affinities of top and bottom fractions (Table III). Hb AS blood is abnormal, however, in that the denser, older red cells have a lower affinity for oxygen than the younger cells. A subject heterozygous both for $\mathrm{Hb} \mathrm{S}$ and for the gene for hereditary persistence of fetal hemoglobin (39) was also studied (Table III). The blood of this nonanemic subject ( $\mathrm{Hb} 14.5 \mathrm{~g} / 100$ $\mathrm{ml}$ ) contained $20 \%$ of $\mathrm{Hb} \mathrm{F}$ (shown to be evenly dis- tributed from cell to cell in Kleihauer preparations) and $80 \% \mathrm{Hb} \mathrm{S}$. There were no deformed cells either in whole blood or in the bottom fraction from the ultracentrifuge tube. Results for $\mathrm{MCHC}$ and $\mathrm{P}_{50}$ were in the same range as those for $\mathrm{Hb}$ AS blood.

\section{DISCUSSION}

It has been shown before that hemoglobin concentration $(\mathrm{MCHC})$ varies considerably from cell to cell in any one population of $\mathrm{Hb} \mathrm{SS}$ erythrocytes $(33,38)$, as does the content of $\mathrm{Hb} \mathrm{F}(33,40)$. Our results indicate that the concentration of 2,3-DPG and the oxygen affinity also vary widely (Table II, Figs. 3 and 4 ) and that, in particular, a subpopulation of cells can be separated which has a very low oxygen affinity associated, paradoxically, with a normal, or slightly subnormal, concentration of 2,3-DPG. These low-oxygen-affinity cells can be separated out of the whole cells population because of their density; they concentrate in the bottom layer of the centrifuge tube and, in smears, they can be identified as ISC. They have a low Hb F content compared with other cells in the whole population (Table II), and their most important characteristic is probably their very low oxygen affinity. These cells, however, are capable of usual reactions with oxygen (Figs. 4 and 5) as had been previously suspended by the ultrastructural demonstration (41) that the hemoglobin in these cells is not necessarily "sickled." There may be a range of cells, with an increasing MCHC, on the way to be- 
coming ISC (presumably by repeated sickling-unsickling and loss of membrane $(42,43))$, so their function as well as their configuration is important. The variability of oxygen affinity among $\mathrm{Hb} \mathrm{SS}$ blood samples appears to be due, not to the 2,3-DPG level, but to the varying numbers of low-affinity, high-MCHC red cells which the blood contains (Table I and Fig. 1).

The relationships among $\mathrm{Hb} \mathrm{F}$ content, $\mathrm{MCHC}$, oxygen affinity, and 2,3-DPG in the fractions which we separated from whole populations of $\mathrm{Hb} \mathrm{SS}$ erythrocytes are intricate. We will therefore discuss each variable in turn in attempting to evaluate the main factor responsible for the low oxygen affinity of $\mathrm{Hb} \mathrm{SS}$ blood.

$H b F$. The proportion of $\mathrm{Hb} \mathrm{F}$ is unlikely to alter as the cell ages, so the very low $\mathrm{Hb} \mathrm{F}$ found in the densest cells must be an initial characteristic of those cells (as previously suggested (33)), perhaps determining their tendency to become dense and to develop a low oxygen affinity and a low 2,3-DPG. As a result, low $\mathrm{Hb} \mathrm{F}$ is associated with low oxygen affinity in the bottom fractions (Table II). The converse, a high $\mathrm{Hb}$ $F$ with a high oxygen affinity, was not a constant finding in the middle and top fractions. A closer examination of the data for $\mathrm{Hb} \mathrm{F}$ in the fractions indicates that its level cannot be the only determinant of oxygen affinity. For several narrow ranges of $\mathrm{Hb} \mathrm{F}$ we found $\mathrm{P}_{\mathrm{5} 0}$ values varying by as much as $25 \mathrm{~mm} \mathrm{Hg}$.

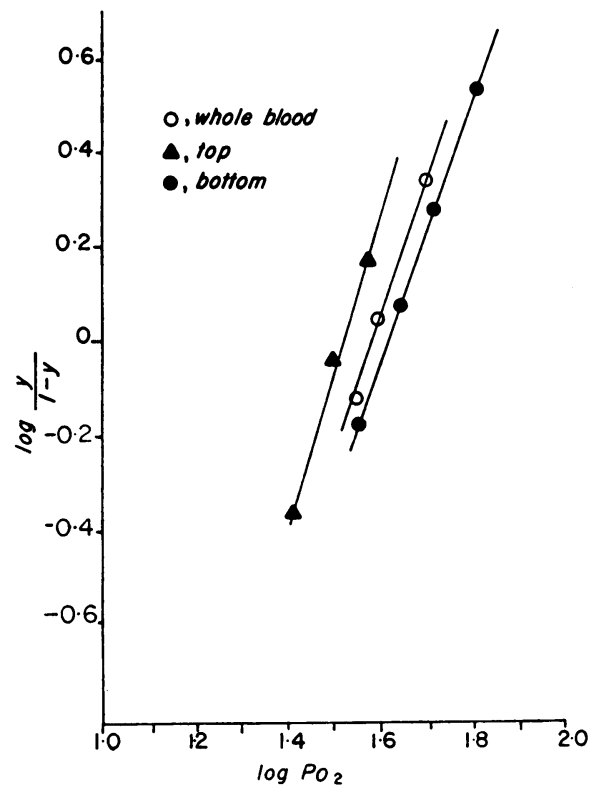

Figure $6 \mathrm{O}_{2}-\mathrm{Hb}$ equilibrium curves for top, bottom, and whole $\mathrm{Hb}$ SS blood determined by the mixing technique and shown as a Hill plot. Top, $\mathrm{P}_{50(7.4)}=33.5 \mathrm{~mm} \mathrm{Hg}, n=$ 3.3; bottom, $\mathrm{P}_{50}=42.0 \mathrm{~mm} \mathrm{Hg}, n=2.9$; whole blood, $\mathrm{P}_{50}$ $=38.0 \mathrm{~mm} \mathrm{Hg}, n=2.9$.
In spite of the high level of $\mathrm{Hb} F$ in all the fractions from the blood of the subject heterozygous both for $\mathrm{Hb}$ $\mathrm{S}$ and for the gene for hereditary persistence of $\mathrm{Hb} \mathrm{F}$, the bottom fraction $P_{s o}$ was still higher than that of the top (Table III). Conversely, in patient J. B. (Table I) $\mathrm{Hb} \mathrm{F}$ was negligible in all fractions, yet $\mathrm{P}_{\mathrm{s}_{0}}$ was $50.8,56.6$, and $66.2 \mathrm{~mm} \mathrm{Hg}$ in top, middle, and bottom fractions, respectively.

Oxygen affinity and 2,3-DPG. Bellingham, Detter, and Lenfant (44), using the mixing technique, calculated that an increase in 2,3-DPG of $1 \mu \mathrm{mol} / \mathrm{g} \mathrm{Hb}$, in normal cells, increases the $\mathrm{P}_{\text {so }}$ by $0.69 \mathrm{~mm} \mathrm{Hg}$ at $\mathrm{pH}$ 7.4. The mean 2,3-DPG (Table II) of our top fraction $\mathrm{Hb} \mathrm{SS}$ erythrocytes was $6.1 \mu \mathrm{mol} / \mathrm{g} \mathrm{Hb}$ more than that for normal top fractions (Table III), reflecting, under normal circumstances, a mean $\mathrm{P}_{50}(\mathrm{pH}$ 7.4) increase of 4.21 $\mathrm{mm} \mathrm{Hg}$. The mean increase for the top fraction cells in our series, using the Bellingham and Huehns technique ( $\mathrm{pH} 7.13$ ), was $14 \mathrm{~mm} \mathrm{Hg}$. $\mathrm{O}_{2}-\mathrm{Hb}$ dissociation curves were highly reproducible by the Bellingham and Huehns technique (see Methods), and a large number of points could be established for each curve even with the small volumes of blood available from ultracentrifuge samples. It is not, however, possible to extrapolate the results in phosphate buffer at $\mathrm{pH} 7.13$ to compare with the mixing technique, where a standard correction is applied to each $\mathrm{Po}_{2}$ value to construct a curve for a plasma $\mathrm{pH}$ of 7.4. In both techniques blood is deoxygenated, and with sickle cell anemia red cells it is possible that future equilibration at higher oxygen pressures does not result in the same degree of oxygen saturation as would result if no deoxygenation "stress" had been applied. In vivo, sickle blood is probably never subjected to complete deoxygenation (as produced by a vacuum pump) for as long as $9 \mathrm{~min}$. In this respect the results of Lian, Roth, and Harkness (45) are interesting. Using a polarographic method, they measured continuous dissociation $(\downarrow)$ and association ( $\uparrow$ ) curves of red cells in phosphate buffer $\mathrm{pH} 7.4$ at $37^{\circ} \mathrm{C}$, and found that the $\mathrm{P}_{\text {so }}$ of $\mathrm{Hb} \mathrm{SS}$ and $\mathrm{Hb}$ AS cells was much lower than $\mathrm{P}_{50} \uparrow$, whereas with $\mathrm{Hb}$ AA cells the difference was only $3 \mathrm{~mm} \mathrm{Hg}$. The difference was greater at higher levels of 2,3-DPG, and was virtually abolished in $\mathrm{Hb} \mathrm{SS}$ cells depleted of 2,3-DPG by incubation in $20 \mathrm{mM}$ sodium bisulphite for $4 \mathrm{~h}$ at $37^{\circ} \mathrm{C}, \mathrm{pH} \mathrm{7.2}$. They considered that, particularly with cells capable of sickling, the descending curve represented more physiologic conditions than the ascending curve.

To test the validity of our results we obtained sufficient blood from an additional $\mathrm{Hb} \mathrm{SS}$ patient to determine the oxygen affinity by a mixing technique (30), using a Corning ${ }^{7}$ oxygen electrode and a Corning aspi-

${ }^{7}$ Corning Glass Works, Corning, N. Y. 
ration $\mathrm{pH}$ electrode at $37^{\circ} \mathrm{C}$. Red cells from ultracentrifuged blood fractions were resuspended in their own plasma to a hematocrit of $25 \%$. Results for $\mathrm{P}_{\mathrm{s0}}(7.4)$ on whole blood, top and bottom fractions are shown in Fig. 6. In this instance $P_{50}$ (7.) for the top fraction was $33.5 \mathrm{~mm} \mathrm{Hg}, 7.5 \mathrm{~mm} \mathrm{Hg}$ higher than controls on normal whole blood $(26 \pm 1 \mathrm{~mm} \mathrm{Hg})$. For the bottom fraction $P_{50}(7.4)$ was $41.8 \mathrm{~mm} \mathrm{Hg}, 15.8 \mathrm{~mm} \mathrm{Hg}$ to the right of normal whole blood. It would seem that the increased 2,3-DPG in the top fraction erythrocytes in sickle cell anemia could account for most of the increase in $P_{s o}$, but in the middle and bottom fractions, where $P_{50}$ values are higher and 2,3-DPG values up to $50 \%$ lower, it cannot account for the very low oxygen affinity of these cells. Conclusions based on the Bellingham and Huehns technique would appear to be as valid as those based on a mixing method. We therefore examined our data for an alternative explanation.

$M C H C$. In all $15 \mathrm{Hb} \mathrm{SS}$ patients $\mathrm{MCHC}$ was higher in the middle fraction than in the top and considerably higher in the bottom fraction than in the middle (Fig. 2). The high mean level in the bottom fractions (Table II) was striking compared with normal blood or blood from $\mathrm{Hb}$ AS subjects (Table III). For all the fractions a plot of $\mathrm{P}_{50}$ vs. MCHC showed that all the high-MCHC bottom fractions had high $\mathrm{P}_{50}$ values, whereas the normal-MCHC top fractions all had much lower $P_{50}$ values. The correlation between $P_{50}$ and $\mathrm{MCHC}$ for top and bottom fractions is highly significant $(r=0.90, P<0.001)$. Values for the middle fractions mostly fall slightly to the right of this line, but some fall slightly to the left. After correcting the $\mathrm{MCHC}$ to mean corpuscular $\mathrm{Hb} \mathrm{S}$ concentrations by subtracting the proportion of $\mathrm{Hb} \mathrm{F}$ in each hemoglobin result, a replot of the data (Fig. 7) showed an even better correlation $(r=0.93)$.

The abnormally high $\mathrm{MCHC}$ of a subpopulation of $\mathrm{Hb}$ SS erythrocytes has been noted previously $(33,38)$, but its significance has not been fully appreciated. The dense, deformed cell called the ISC is but the end stage in a process of membrane loss $(42,43)$ and consequent concentration of corpuscular hemoglobin. The recent work of May and Huehns (46) supports the concept that erythrocyte concentration of $\mathrm{Hb} \mathrm{S}$ is important in altering the oxygen affinity of these cells. They found that depletion of 2,3-DPG shifted the $\mathrm{P}_{\mathrm{so}}$ of normal red cells (at $\mathrm{pH} 7.13$ ) from 30.5 to $20.0 \mathrm{~mm} \mathrm{Hg}$, and the $\mathrm{P}_{\mathrm{so}}$ of $\mathrm{Hb}$ SS cells from 46.0 to $32.0 \mathrm{~mm} \mathrm{Hg}$. They also produced a series of red cells, of different MCHC by a process of "osmotic lysis" and showed that the oxygen affinity of $\mathrm{Hb}$ SS cells so treated was clearly dependent on the concentration of hemoglobin in the presence and absence of 2,3-DPG, whereas the oxygen affinity of $\mathrm{Hb} \mathrm{AA}$ cells was only concentration-de-

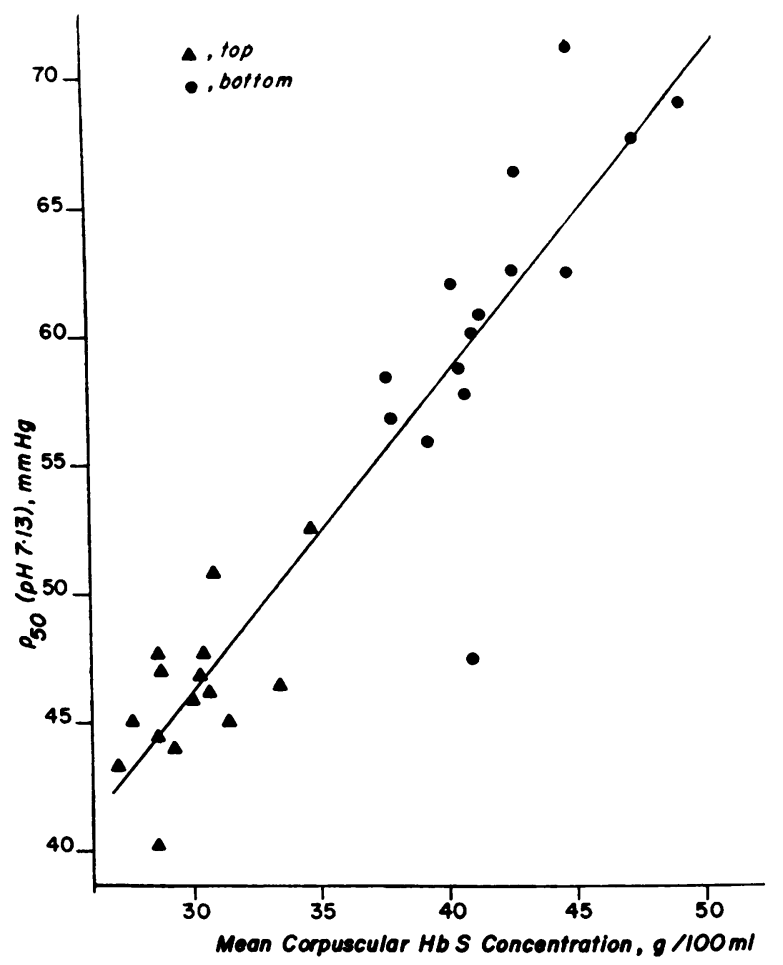

FIgure 7 Relationship between $\mathrm{P}_{\mathrm{s}_{0}}$ and $\mathrm{MCHC}$ of $\mathrm{Hb} \mathrm{SS}$ erythrocytes separated by ultracentrifugation into fractions. The MCHC has been corrected to mean corpuscular $\mathrm{Hb} \mathrm{S}$ concentration by subtraction of alkali resistant hemoglobin (see methods). The regression line is drawn for top and bottom fractions from the equation $P_{s 0}(7.18)=1.207 \mathrm{MC}(\mathrm{Hb}$ S) C + 10.1. $(r=0.93, P<0.001)$.

pendent in the presence of 2,3-DPG. On the other hand, Bromberg and Andrade (31) found that the difference in oxygen affinity between $\mathrm{Hb}$ SS blood and normal blood was almost entirely abolished when red cells were depleted of 2,3-DPG. In view of the striking difference in oxygen affinity of top (high 2,3-DPG) and bottom (low 2,3-DPG) such a result would only be expected in the mildest (low ISC) cases of sickle cell anemia. We used blood from patient J. B. (Table I) and

\section{TABLE IV}

Effect of Depletion of 2,3-DPG on $P_{50}$ of Normal and Sickle Cell Anemia Erythrocytes

\begin{tabular}{|c|c|c|c|}
\hline & $P_{60}(7.13)$ & DPG & $P_{s 0}$ before $/ P_{b c}$ after \\
\hline Hb AA & $m m B g$ & $\mu \mathrm{mol} / \mathrm{s} \mathrm{Hb}$ & \\
\hline $\begin{array}{l}\text { before: } \\
\text { depleted: }\end{array}$ & $\begin{array}{l}30.2 \\
22.5\end{array}$ & $\begin{array}{r}14.2 \\
2.1\end{array}$ & 1.34 \\
\hline \multicolumn{4}{|l|}{$\mathrm{Hb}$ SS } \\
\hline $\begin{array}{l}\text { before: } \\
\text { depleted: }\end{array}$ & $\begin{array}{l}54.7 \\
45.7\end{array}$ & $\begin{array}{r}16.3 \\
1.1\end{array}$ & 1.20 \\
\hline
\end{tabular}


incubated it for $24 \mathrm{~h}$ under sterile conditions with added glucose. The ratio $P_{50}$ fresh cells $/ P_{50}$-depleted cells was comparable for both $\mathrm{Hb} \mathrm{AA}$ and $\mathrm{Hb}$ SS blood, but the $\mathrm{P}_{50}$ of the depleted $\mathrm{Hb} \mathrm{SS}$ blood was still shifted to the right of normal (Table IV). Recent work on the effect of cyanate on hemoglobin $(47,48)$ has again indicated the differences between normal red cells and sickle cell red cells with regard to oxygen affinity when cells are depleted of 2,3-DPG. Beutler, Paniker, and West (49) looked for a special effect of 2,3-DPG on $\mathrm{Hb} \mathrm{S}$ and, at first, were unable to demonstrate one (49). More recently (50) they have re-examined their data and clarified these results. As well as the obvious effect of lowering the oxygen saturation at any given $\mathrm{P}_{\mathbf{o}_{2}}$, it now appears that, at any given saturation with oxygen, $\mathrm{Hb} \mathrm{S}$ becomes more viscous at increasing concentrations of 2,3-DPG. Difference electron density maps of human deoxyhemoglobin with 2,3-DPG attached have also indicated the possibility of a twofold effect of 2,3-DPG on $\mathrm{Hb} \mathrm{S}$. The distance between glutamic acid residues at $6 \beta_{1}$ and $6 \beta_{2}$ in deoxyhemoglobin $A$ is about $2 \AA$ shorter in the presence of DPG than in its absence (51). The significance of this molecular alteration is unknown at present, but it would suggest that the distance between the valines at the $6 \beta$ position in $\mathrm{Hb} \mathrm{S}$ would also be shorter and, if this were so, it might explain the effect of increasing concentrations of 2,3-DPG on the viscosity of $\mathrm{Hb} \mathrm{S}(50)$. In this respect, the findings of Lian and collaborators already referred to (45) are pertinent. When they artificially increased red cell 2,3DPG by incubation with inosine and pyruvate, they found that $\Delta \mathrm{P}_{50} / \Delta 2,3-\mathrm{DPG}$ was greater in $\mathrm{Hb} \mathrm{SS}, \mathrm{AS}$, and $\mathrm{SC}$ cells than in $\mathrm{Hb} \mathrm{AA}, \mathrm{AC}$, and $\mathrm{CC}$ red cells. Our results indicate that the effects of 2,3-DPG and increased $\mathrm{Hb} \mathrm{S}$ concentration are in the same direction and probably additive.

It is difficult to account for the low 2,3-DPG content of high MCHC cells and further work is needed to measure the intracellular $\mathrm{pH}$ of top, middle, and bottom cells. We found a normal Bohr effect $\left(\Delta \log \mathrm{Po}_{\mathrm{o}:} / \Delta \mathrm{pH}\right)$ of -0.464 in 'bottom' $\mathrm{Hb}$ SS cells equilibrated in phosphate buffers. Preliminary results suggest, at present, that there is little difference in intracellular $\mathrm{pH}$ between top and bottom cells. By the freeze-thaw method (52) both had a $\mathrm{pH}$ of $7.15\left(37^{\circ} \mathrm{C}\right)$ at plasma $\mathrm{pH} 7.45$. This is understandable. The difference between plasma and intracellular $\mathrm{pH}(\Delta \mathrm{pH})$ in top cells could be due to their high content of the highly charged anion 2,3-DPG, since it has been shown (44) that there is a correlation between $\Delta \mathrm{pH}$ and 2,3-DPG. The $\Delta \mathrm{pH}$ of bottom cells could be accounted for by increased hemoglobin concentration and the Donnan equilibrium effect. The mechanisms that control the level of 2,3-DPG (both free and $\mathrm{Hb}$ bound) are not clearly understood. It is also pos- sible that, as the concentration of $\mathrm{Hb} \mathrm{S}$ increases, the $N$-terminal valines of the $\beta$-chain (one of the sites for 2,3-DPG binding) are involved in the process of intermolecular aggregation and are therefore not available to 2,3-DPG. The synthesis of 2,3-DPG in these cells would lessen as the extent of intermolecular aggregation increased.

Messer and Harris (53) showed that, within $0.12 \mathrm{~s}$ of sudden deoxygenation, $\mathrm{Hb} \mathrm{SS}$ cells had a decreased filterability (increased rigidity), but this did not occur until $0.5 \mathrm{~s}$ with $\mathrm{Hb} \mathrm{SC}$ cells, and no change was observed with $\mathrm{Hb}$ AS cells within $5 \mathrm{~s}$. The extent to which hemoglobin species (deoxy $\mathrm{Hb} \mathrm{S}+\mathrm{A}$, deoxy $\mathrm{S}+\mathrm{F}$, etc.) interact $(54,55)$ determines whether aggregates are formed at any given saturation but other parameters, such as 2,3-DPG and hemoglobin concentration, have an effect by lowering the saturation for any given $\mathrm{P}_{0_{2}}$. We cannot find precise data for the physical state of hemoglobin in $\mathrm{Hb}$ SS cells at various oxygen pressures, but it seems likely that, in cells with a high concentration of $\mathrm{Hb} \mathrm{S}$, quite small decreases in $\mathrm{P}_{0_{2}}$ initiate molecular aggregation. Whatever the molecular surface interactions responsible for this aggregation, the reason for the decrease in oxygen affinity with increasing $\mathrm{Hb} \mathrm{S}$ concentration could be a simple thermodynamic effect. To oxygenate the crystalline $\mathrm{Hb} \mathrm{S}$ aggregate, the lattice energy must be supplied as well as the normal constraints of the deoxy structure (56) overcome. Other workers (28) have suggested this mechanism to explain the low oxygen affinity of sickle cell blood.

The result of a decreased oxygen affinity is a greater oxygen release capacity per gram of circulating hemoglobin, whether this be mediated through increased erythrocyte $2,3-\mathrm{DPG}(13,14,18,19)$, through an intrinsic defect in the hemoglobin molecule producing a low affinity (22), or through increased molecular interaction on deoxygenation, as in $\mathrm{Hb} \mathrm{SS}$ blood (28). In the erythrocytes of our top fractions the first and third mechanisms are probably operating, but in the high density ISC the low oxygen affinity appears to be due to high hemoglobin concentration alone. Rodman, Close, and Purcell (17) examined the greater oxygen release capacity in persons with anemia ( $\mathrm{Hb} 6.5 \mathrm{~g} / 100 \mathrm{ml}$ ) who had $P_{50}$ values $10-20 \mathrm{~mm} \mathrm{Hg}$ greater than normal. They calculated a $90 \%$ improvement in oxygen release equivalent to a circulating hemoglobin level of $9.5 \mathrm{~g} / 100 \mathrm{ml}$ of blood with a normal $\mathrm{O}_{2}-\mathrm{Hb}$ equilibrium curve. Increased cardiac output could improve the situation further. By this concept lowered oxygen affinity is a compensation for anemia. The $\mathrm{Hb}$ Seattle patients who have low oxygen affinity blood, however, have lownormal urinary erythropoietin outputs in spite of hematocrit levels of $24-33 \%$ (22). In these patients the low 
hematocrits appear to be a normal response to the greater oxygen release capacity of a blood with lowered oxygen affinity. The hematocrit level is normally regulated by the level of "erythropoietic-stimulating factor" produced by the kidney (57), which is thought to be controlled by intrarenal $\mathrm{P}_{\mathrm{o}_{2}}$. In discussing the mechanism of hematocrit control in patients having abnormal hemoglobins with altered oxygen affinity, Parer (58) pointed out that venous $\mathrm{P}_{0_{2}}$ (and, by extrapolation, renal $\mathrm{P}_{\mathrm{O}_{2}}$ ) would vary directly with oxygen capacity for any particular hemoglobin variant. We suggest that $\mathrm{Hb}$ SS erythrocytes behave, in this respect, like $\mathrm{Hb}$ Seattle erythrocytes so that, to a considerable extent, the hematocrit levels in sickle cell anemia in the steady state is determined by the oxygen affinity of the blood and not vice-versa, as in the usual 2,3-DPG-mediated response to anemia.

Finally, the desaturation of arterial blood in some patients may be explained on the basis of our findings. Other workers $(59,60)$ have found this desaturation, and some have noted that it occurred in the presence of normal or adequate arterial $\mathrm{P}_{0_{2}}$ (61) and attributed it to the altered oxygen affinity of the blood. It can be seen from Fig. 4 that the high-density erythrocytes may not achieve normal oxygen saturation levels at normal alveolar $\mathrm{P}_{0.2}$. Patients having the highest numbers of these cells on the venous side of the circulation (and the lowest oxygen affinity as a result) might be found to have the lowest arterial oxygen saturation. This would also explain the reported finding of a few "sickled cells" (presumably ISC) in arterial blood samples $(57,58)$.

\section{ACKNOWLEDGMENTS}

We are grateful to Mrs. F. Taylor, Miss H. Gooden, Miss C. McKesey, and Miss J. Wardle, Hematology subdepartment, University of the West Indies, for technical assistance. We are also grateful to Doctors A. Bellingham and E. R. Huehns of University College Medical School, London, for instruction in their method for oxygen dissociation curves, and to Dr. S. Charache and Mrs. E. Gayle for results using the mixing technique.

The work was supported by grants from the Wellcome Trust and the Research Corporation.

\section{REFERENCES}

1. Christensen, E. H., and D. B. Dill. 1935. Oxygen dissociation curves of bird blood. J. Biol. Chem. 109: 443.

2. Hill, R., and H. P. Wolvekamp. 1936. The oxygen dissociation curve of haemoglobin in dilute solution. Proc. R. Soc. Edinb. Sect. Biol. B. 120: 484.

3. Drake, E. N., S. J. Gill, M. Downing, and C. P. Malone. 1963. The environmental dependency of the reaction of oxygen with hemoglobin. Arch. Biochem. Biophys. 100: 26.

4. Benesch, R., R. E. Benesch, and C. I. Yu. 1968. Reciprocal binding of oxygen and diphosphoglycerate by human hemoglobin. Proc. Natl. Acad. Sci. U. S. A. 59: 526.
5. Benesch, R., and R. E. Benesch. 1967. The effect of organic phosphates from the human erythrocyte on the allosteric properties of hemoglobin. Biochem. Biophys. Res. Commun. 26: 162.

6. Chanutin, A., and R. R. Curnish. 1967. Effect of organic and inorganic phosphates on the oxygen equilibrium of human erythrocytes. Arch. Biochem. Biophy's. $121: 96$.

7. Benesch, R., and R. E. Benesch. 1969. Intracellular organic phosphates as regulators of oxygen release by haemoglobin. Nature (Lond.). 221: 618.

8. Bunn, H. F., and R. W. Briehl. 1970. The interaction of 2,3-diphosphoglycerate with various human hemoglobins. J. Clin. Invest. 49 : 1088.

9. Oski, F. A., A. J. Gottlieb, M. Delivoria-Papadopoulos, and W. W. Miller. 1969. Red-cell 2,3-diphosphoglycerate levels in subjects with chronic hypoxemia. N. Engl. J. Med. 280: 1165 .

10. Bunn, H. F., and J. H. Jandl. 1970. Control of hemoglobin function within the red cell. N. Engl. J. Med. 282: 1414.

11. Edwards, M. J., M. J. Novy, C-L. Walters, and J. Metcalfe. 1968. Improved oxygen release: an adaptation of mature red cells to hypoxia. J. Clin. Invest. 47: 1851.

12. Lenfant, C., P. Ways, C. Aucutt, and J. Cruz. 1969. Effect of chronic hypoxic hypoxia on the $\mathrm{O}_{2}-\mathrm{Hb}$ dissociation curve and respiratory gas transport in man. Respir. Physiol. $7: 7$.

13. Lenfant, C., J. Torrance, E. English, C. A. Finch, C. Reynafarje, J. Ramos, and J. Faura. 1968. Effect of altitude on oxygen binding by hemoglobin and on organic phosphate levels. J. Clin. Invest. 47: 2652.

14. Woodson, R. D., J. D. Torrance, S. D. Shappell, and C. Lenfant. 1970. The effect of cardiac disease on hemoglobin-oxygen binding. J. Clin. Invest. 49: 1349.

15. Richards, D. W., and M. L. Strauss. 1927. Oxy-hemoglobin dissociation curves of whole blood in anemia. J. Clin. Invest. 4 : 105.

16. Kennedy, A. C., and D. J. Valtis. 1954. The oxygen dissociation curve in anemia of various types. J. Clin. Invest. 33: 1372.

17. Rodman, T., H. P. Close, and M. K. Purcell. 1960. The oxyhemoglobin dissociation curve in anemia. Ann. Intern. Med. 52: 295.

18. Hjelm, M. 1969. The content of 2,3-diphosphoglycerate and some other phosphocompounds in human erythrocytes from healthy adults and subjects with different types of anemia. Försvarsmedicin. 5 : 219.

19. Torrance, J., P. Jacobs, A. Restrepo, J. Eschbach, C. Lenfant, and C. A. Finch. 1970. Intraerythrocytic adaptation to anemia. N. Engl. J. Med. 283: 165.

20. Charache, S., D. J. Weatherall, and J. B. Clegg. 1966. Polycythemia associated with a hemoglobinopathy. $J$. Clin. Invest. $45: 813$.

21. Novy, M. J., M. J. Edwards, and J. Metcalfe. 1967. Hemoglobin Yakima: II. High blood oxygen affinity associated with compensatory erythrocytosis and normal hemodynamics. J. Clin. Invest. 46: 1848.

22. Stamatoyannopoulos, G., J. T. Parer, and C. A. Finch. 1969. Physiologic implications of a hemoglobin with decreased oxygen affinity (hemoglobin Seattle). N. Engl. J. Med. 281: 915 .

23. May, A., and E. R. Huehns. 1972. The control of oxygen affinity of red cells with Hb-Shepherds Bush. Br. J. Haematol. $22: 599$.

Oxygen Affinity in Sickle Cell Anemia 
24. Tyuma, I., and K. Shimizu. 1969. Different response to organic phosphates of human fetal and adult hemoglobins. Arch. Biochem. Biophys. 129: 404.

25. Tyuma, I., and K. Shimizu. 1970. Effect of organic phosphates on the difference in oxygen affinity between fetal and adult human hemoglobin. Fed. Proc. 29: 1112.

26. Becklake, M. R., S. B. Griffiths, M. McGregor, H. I. Goldman, and J. P. Schreve. 1955. Oxygen dissociation curves in sickle cell anemia and in subjects with the sickle cell trait. J. Clin. Invest. 34 : 751.

27. Fraimow, W., T. Rodman, H. P. Close, R. Cathcart, and M. K. Purcell. 1958. The oxyhemoglobin dissociation curve in sickle cell anemia. Am. J. Med. Sci. 236: 225.

28. Bromberg, P. A., and W. N. Jensen. 1967. Blood oxygen dissociation curves in sickle cell disease. J. Lab. Clin. Med. 70: 480.

29. Allen, D. W., and J. Wyman, Jr. 1954. Equilibre de l'hémoglobine de drépanocytose avec l'oxygène. Rev. Hematol. 9 : 155.

30. Charache, S., S. Grisolia, A. J. Fiedler, and A. E. Hellegers. 1970. Effect of 2,3-diphosphoglycerate on oxygen affinity of blood in sickle cell anemia. J. Clin. Invest. 49: 806.

31. Bromberg, P. A., and O. Andrade. 1971. Effect of polymerization of $\mathrm{Hb} \mathrm{S}$ on $\mathrm{O}_{2}$ affinity of sickle cells. Clin. Res. 19 : 412 . (Abstr.)

32. Bellingham, A. J., and E. R. Huehns. 1969. Oxygen dissociation in red cells from patients with abnormal haemoglobins and pyruvate kinase deficiency. Försvarsmedicin. 5: 207.

33. Bertles, J. F., and P. F. A. Milner. 1968. Irreversibly sickled erythrocytes: a consequence of the heterogeneous distribution of hemoglobin types in sickle-cell anemia. J. Clin. Invest. 47 : 1731.

34. Bellingham, A. J., and E. R. Huehns. 1968. Compensation in haemolytic anaemias caused by abnormal haemoglobins. Nature (Lond.). 218: 924.

35. Beutler, E., A. Meul, and L. A. Wood. 1969. Depletion and regeneration of 2,3-diphosphoglyceric acid in stored red blood cells. Transfusion (Phila.). 9: 109.

36. Krimsky, I. 1965. D-2,3-diphosphoglycerate. In Methods of Enzymatic Analysis. H. U. Bergmeyer, editor. Academic Press, Inc., New York and London. 238.

37. Betke, K., H. R. Marti, and I. Schlicht. 1959. Estimation of small percentages of foetal haemoglobin. Nature (Lond.). $184: 1877$.

38. Chien, S., S. Usami, and J. F. Bertles. 1970. Abnormal rheology of oxygenated blood in sickle cell anemia. $J$. Clin. Invest. $49: 623$.

39. Conley, C. L., D. J. Weatherall, S. N. Richardson, M. K. Shepard, and S. Charache. 1963. Hereditary persistence of fetal hemoglobin: a study of 79 affected persons in 15 Negro families in Baltimore. Blood. 21: 261.

40. Shepard, M. K., D. J. Weatherall, and C. L. Conley. 1962. Semi-quantitative estimation of the distribution of fetal hemoglobin in red cell populations. Bull. Johns Hopkins Hosp. 110: 293.

41. Bertles, J. F., and J. Döbler. 1969. Reversible and irreversible sickling: a distinction by electron microscopy. Blood. 33 : 884.

42. Jensen, W. N. 1969. Fragmentation and the "freakish poikilocyte." Am. J. Med. Sci. 257: 355.
43. Jensen, W. N., P. A. Bromberg, and K. Barefield. 1969. Membrane deformation: a cause of the irreversibly sickled cell (ISC). Clin. Res. 17: 464. (Abstr.)

44. Bellingham, A. J., J. C. Detter, and C. Lenfant. 1971. Regulatory mechanisms of hemoglobin oxygen affinity in acidosis and alkalosis. J. Clin. Invest. 50: 700.

45. Lian, C. Y., S. Roth, and D. R. Harkness. 1971. The effect of alteration of intracellular 2,3-DPG concentration upon oxygen binding of intact erythrocytes containing normal and mutant hemoglobins. Biochem. Biophys. Res. Commun. 45 : 151.

46. May, A., and E. R. Huehns. 1972. Mechanism of the low oxygen affinity of red cells in sickle cell disease. Blut. In press.

47. May, A., A. J. Bellingham, E. R. Huehns, and G. H. Beaven. 1972. Effect of cyanate on sickling. Lancet. 1: 658.

48. de Furia, F. G., D. R. Miller, A. Cerami, and J. M. Manning. 1972. The effects of cyanate in vitro on red blood cell metabolism and function in sickle cell anemia. J. Clin. Invest. $51: 566$.

49. Beutler, E., N. V. Paniker, and C. West. 1971. The effect of 2,3-DPG on the sickling phenomenon. Blood $J$. Hematol. 37 : 184.

50. Beutler, E., and N. V. Paniker. 1972. Correspondence. Blood J. Hematol. 39 : 744.

51. Arnone, A. 1972. X-ray diffraction study of binding of 2,3-diphosphoglycerate to human deoxyhaemoglobin. Nature (Lond.). 237: 146.

52. Hilpert, P., R. G. Fleischmann, D. Kempe, and H. Bartels. 1963. The Bohr effect related to blood and erythrocyte pH. Am. J. Physiol. 205: 337.

53. Messer, M. J., and J. W. Harris. 1970. Filtration characteristics of sickle cells: rates of alteration of filterability after deoxygenation and reoxygenation, and correlations with sickling and unsickling. J. Lab. Clin. Med. 76 : 537.

54. Bertles, J. F., R. Rabinowitz, and J. Döbler. 1970. Hemoglobin interaction: modification of solid phase composition in the sickling phenomenon. Science (Wash. D. C.). $169: 375$.

55. Bookchin, R. M., and R. L. Nagel. 1971. Ligand-induced conformational dependence of hemoglobin in sickling interactions. J. Mol. Biol. $60: 263$.

56. Perutz, M. F. 1970. Stereochemistry of cooperative effects in haemoglobin. Nature (Lond.). 228: 726.

57. Erslev, A. 1969. Erythropoietic function of the kidney. In Physiology of the Human Kidney. L. G. Wesson, editor. Grune \& Stratton, Inc., New York. 521.

58. Parer, J. T. 1970. Oxygen transport in human subjects with hemoglobin variants having altered oxygen affinity. Respir. Physiol. 9: 43.

59. Jensen, W. N., D. L. Rucknagel, and W. J. Taylor. 1960. In vivo study of the sickle cell phenomenon. $J$. Lab. Clin. Med. 56: 854.

60. Bromberg, P. A., and W. N. Jensen. 1967. Arterial oxygen unsaturation in sickle cell disease. Am. Rev. Respir. Dis. $96: 400$.

61. Rodman, T., H. P. Close, R. Cathcart, and M. K. Purcell. 1959. The oxyhemoglobin dissociation curve in the common hemoglobinopathies. Am. J. Med. 27: 558. 